\title{
Antibodies to Newcastle Disease Virus in Egg Yolks of Great Cormorant (Phalacrocorax carbo) at Qinghai Lake
}

\author{
Alexander Y. Alekseeev1,2,3, Kirill A. Sharshov',2,3, Vasiliy Y. Marchenko4, Zhuo Li'1, \\ Jian Cao1, Fang Yang1, Alexander M. Shestopalov',3, Vyacheslav A. Shkurupy², Laixing Li1* \\ ${ }^{1}$ Northwest Institute of Plateau Biology, Chinese Academy of Sciences, Xining, China \\ ${ }^{2}$ Research Center of Clinical and Experimental Medicine, Siberian Branch of Russian Academia Medical Science, \\ Novosibirsk, Russia \\ ${ }^{3}$ Novosibirsk State University, Novosibirsk, Russia \\ ${ }^{4}$ State Research Center of Virology and Biotechnology "Vector", Novosibirsk, Russia \\ Email: ${ }^{*}$ xli@nwipb.cas.cn
}

Received 5 October 2014; revised 15 November 2014; accepted 24 November 2014

Copyright (C) 2014 by authors and Scientific Research Publishing Inc.

This work is licensed under the Creative Commons Attribution International License (CC BY).

http://creativecommons.org/licenses/by/4.0/

(c) (i) Open Access

\section{Abstract}

Newcastle disease virus (NDV) is not considered as cause of serious disease in humans. But, recent data make it clear that, under particular circumstances, it is indeed possible for NDV to cause severe human respiratory disease. Newcastle Disease infection has been reported in many bird species. Cormorants that inhabit at the Qinghai-Tibet Plateau are mainly represented by Great Cormorant (Phalacrocorax carbo sinensis), which is distributed mainly on the Qinghai Lake area. Cormorants are considered as one of the main NDV-reservoir. We conducted the study for the presence of antibodies to Newcastle disease virus by hemagglutination inhibition test in yolks. We got $50 \%$ of seropositive yolks to Newcastle disease virus. These results show that NDV circulates in the Qinghai Lake population of cormorants. We first used the technique of detection of antibodies to Newcastle disease virus in the egg yolk for study the circulation of the virus in cormorants and demonstrated its effectiveness. We should carefully monitor cases of pneumonia in the population of people living around the lake and assess the causes of the disease.

\section{Keywords}

Newcastle Diseases Virus, Antibodies, Egg Yolk, Great Cormorant, Hemagglutination Inhibition Test

\footnotetext{
*Corresponding author.
} 


\section{Introduction}

We report the results of the study for the presence of antibodies to Newcastle disease virus by hemagglutination inhibition test in Great Cormorant yolks at Qinghai Lake.

Since 1926, when the first Newcastle disease (ND) outbreaks were registered, many countries reported disease which causes enormous economic losses. ND is caused by virulent strains of Newcastle disease virus (NDV) which belongs to Avulavirus genus of the Paramyxoviridae family.

NDV can infect a great variety of poultry or free-living birds, and such infections play a role for control activity of poultry industry. NDV have been reported in at least 241 species of birds representing 27 of the 50 orders of the class [1] including exotic birds, as clinically ill and apparently healthy. It seems that many bird species are susceptible to infection with the NDV, but do not always show clinical signs of the disease. Outbreaks of Newcastle disease regularly reported in many countries around the world, such as Australia, Korea and California, which caused major poultry deaths [2]. The virus is not considered a cause of serious disease in humans. Cases of human infection with Newcastle disease virus are rare and have been reviewed periodically [3]. However, recent data make it clear that, under particular circumstances, it is indeed possible for NDV to cause severe human respiratory disease [4].

Cormorants are considered one of the main NDV-reservoir. The world range of the Great Cormorant (Phalacrocorax carbo) extends discontinuously from north-east America (Labrador and Newfoundland) across Eurasia to Australia and New Zealand, as well as to South Africa. The distribution is far from continuous, especially in Europe and central Asia [5]. Cormorants that inhabit the Qinghai-Tibet Plateau are mainly represented by Great Cormorant (Phalacrocorax carbo sinensis), which is distributed mainly on the Qinghai Lake area. Cormorant-like viruses represent an interesting biological system because, together with pigeon-like NDV, they represent the two known natural reservoirs of virulent viruses in wild birds through the world [6] [7].

Accurate diagnosis of virus requires combining various methods such as analysis of clinical symptoms (including histological analysis), the virus cultivation and serological analysis [8]. Also very common method is the detection of NDV antibodies by hemagglutination inhibition (HI) test [9] [10]. It is known that antibodies to a variety of bird infections can be found in egg yolks. This may indicate to pathogen circulation and the presence population immunity.

The study was aimed on analysis of the NDV antibodies presence in egg yolks of Great Cormorant (Phalacrocorax carbo) at Qinghai Lake in 2012.

\section{Materials and methods}

We sampled 60 egg yolks of the Great Cormorant at Qinghai Lake in April 2012. We conducted the study for the presence of antibodies to Newcastle disease virus by HI. As the antigen we used commercial "Newcastle Disease Virus Antigen” produced by Harbin Weike Biotechnology Co., China. Before study all tested yolks were treated with RDE (Denka Seiken, Tokyo, Japan) that destroys non-specific inhibitors [11] [12]. We added 25 mcl of 4 Hemagglutination Unit of Newcastle Disease Virus Antigen to 25 mcl of yolk 2-fold dilutions, incubated at room temperature for $60 \mathrm{~min}$ and added $50 \mathrm{mcl}$ of $0.5 \%$ chicken erythrocytes suspension in each well of the plate. Yolks were considered positive if the HI antibody titer was equal to or greater than 40 [11] [12]. We also conducted negative and positive controls of $0.5 \%$ chicken erythrocytes suspension, and negative controls of yolk with $0.5 \%$ chicken erythrocytes suspension.

\section{Results and Discussion}

We found 50\% egg yolks having significant HI antibody titer-more than 1/40 (Table 1). More than half of seropositive yolks had the titer 1/160-1/320. Five samples had the high titer 1/640 and more.

NDV causes many outbreaks among poultry and economic losses in different countries. NDV epizootics were registered in 29 countries in 2013 according to the OIE. Previous studies showed that cormorants are classical reservoir of Paramyxoviruses, in particular NDV. Qinghai Lake is the lake of great concentration of wild birds and consequently the center of favorable factors for the development of many diseases in birds. A large number of cormorants inhabits at Qinghai Lake.

It is known the birds transfer maternal antibodies (MAb) to their offspring through the egg yolk where the antibody is absorbed and enters the circulatory system. MAb are pathogen specific antibodies that are passed from 
Table 1. HI test results of Cormorant egg yolk for presence of antibodies to NDV antigen.

\begin{tabular}{ccccccc}
\hline & & \multicolumn{5}{c}{ Positive result } \\
\cline { 3 - 7 } Subtype & Total & \multicolumn{5}{c}{ Titer } \\
& samples & \multicolumn{4}{c}{$1 / 30$} & $1 / 640$ and more \\
\cline { 3 - 7 } & & $1 / 40$ & $1 / 80$ & $1 / 160$ & $1 / 320$ & 5 \\
\hline
\end{tabular}

the hen to the chick through the egg yolk. MAb are absorbed from the yolk into the circulatory system of the chick and can behave similarly to naturally induced antibody.

Since animal welfare is an issue of great concern, there is a need for alternative sources of antibodies that could be produced without pain and distress to the animal [11]. The availability of egg yolk antibody instead of serum, as an economic and attractive alternative in sampling, as well as addressing animal welfare concerns, makes exploration of this antibody in disease monitoring feasible, especially for viruses surveillance in birds without causing stress [12].

We assume that the population of cormorants on the Qinghai is a reservoir of NDV. A similar pattern was shown for other regions, including the species of birds that migrate through the high mountain lakes [10]. For instance, no strains of pathogenic genotype 5b NDV repeatedly detected in cormorants in the south of Russia [6], the infection rate was $11.1 \%$. At the seaside territory in the east of Russia by the same authors also NDV strains have been isolated from cormorants. Virulent NDV (vNDV) is exotic in poultry in the United States; however, the virus has been frequently associated with outbreaks of ND in cormorants, which poses a significant threat to poultry species [7].

Currently the NDV is not considered as a serious treat to humans. Human infection cases with Newcastle disease virus are rare and have been reviewed periodically [3]. It is well known that NDV can cause an acute and rapidly clearing conjunctivitis. The first such case was reported by Macfarlane Burnet as resulting from a laboratory accident in 1942 [13]. Numerous subsequent ocular infection cases, were clearly documented as attributable to NDV on the basis of serology and virus isolation [14]. Such cases almost always occurred in poultry workers preparing or administering a lyophilized or aerosolized NDV vaccine. By contrast, the association of NDV with human respiratory disease has been more tenuous [14]. Human NDV infection or its relationship to influenzalike symptoms that were based solely on serology, possibly were connected to cross-reactivity with antibodies to mumps or parainfluenza viruses [15]. It was shown the evidence of possible NDV recovery from lung biopsy material from a patient with pneumonia [15]; however, report contained conflicting results, and its conclusions were debated [16]. Nevertheless it is indeed possible for NDV to cause severe human respiratory disease. In 2007 presence the most completely documented report of a pneumonia case, or any systemic human infection, caused by NDV. It was the first report of an association between this virus and a fatal human disease [4].

We have confirmed in our work that Newcastle disease virus circulated in Cormorants from Qinghai Lake, which is home to a large number of wintering and migrating birds. Newcastle disease virus can be transmitted by bird from Qinghai Lake on long distances of large region (China, Russia, etc.). We first showed a large number of samples (50\%) in the wild bird population with a high titer of antibodies to Newcastle disease virus. We first used the technique of detection of antibodies to Newcastle disease virus in the egg yolk for study the circulation of the virus in cormorants and demonstrated its effectiveness. Thus it requires constant monitoring of the situation on NDV circulation in different bird species (wild and domestic) and their population immunity to ND. In addition, we should carefully monitor cases of pneumonia in the population of people living around the areas where the NDV is maintained. Following recent reports of NDV could cause not only mild forms of animal and human diseases, but also the cause of their deaths.

\section{Acknowledgements}

This study was supported by China Ministry of Science and Technology Project 973 (grant no. 2010CB530301), National Science and Technology Pillar Program (grant no. 2008BADBOB0303), RFBR project No. 13-04-91179GFEN-a, USDA grant No. 58-0210-2-040F. 


\section{References}

[1] Alexander, D.J. (2000) Newcastle Disease and Other Avian Paramyxoviruses. Rev Sci Tech., 19, 443-462.

[2] Pedersen, J.C., Senne, D.A., Woolcock, P.R., Kinde, H., King, D.J., Wise, M.G., Panigrahy, B. and Seal, B.S. (2004) Phylogenetic Relationships among Virulent Newcastle Disease Virus Isolates from the 2002-2003 Outbreak in California and Other Recent Outbreaks in North America. Journal of Clinical Microbiology, 45, 2329-2334. http://dx.doi.org/10.1128/JCM.42.5.2329-2334.2004

[3] Capua, I. and Alexander, D.J. (2004) Human Health Implications of Avian Influenza Viruses and Paramyxoviruses. The European Journal of Clinical Microbiology \& Infectious Diseases, 23, 1-6. http://dx.doi.org/10.1007/s10096-003-1059-3

[4] Goebel, S.J., Taylor, J., Barr, B.C., Kiehn, T.E., Castro-Malaspina, H.R., Hedvat, C.V., Rush-Wilson, K.A., Kelly, C.D., Davis, S.W., Samsonoff, W.A., Hurst, K.R., Behr, M.J. and Masters, P.S. (2007) Isolation of Avian Paramyxovirus 1 from a Patient with a Lethal Case of Pneumonia. Journal of Virology, 81, 12709-12714. http://dx.doi.org/10.1128/JVI.01406-07

[5] Zhang, T., Li, L., Lian, X., Cai, Z. and Su, J. (2007) Reproductive Biology of Great Cormorant (Phalacrocorax carbo sinensis) in the Qinghai-Tibet Plateau. Waterbirds, 30, 305-309. http://dx.doi.org/10.1675/1524-4695(2007)30[305:RBOGCP]2.0.CO;2

[6] Usachev, E.V., Shchelkanov, M.Iu., Fediakina, I.T., L’vov, D.N., Dzharkenov, A.F., Aristova, V.A., Kovtunov, A.I., Prilipov, A.G., Iamnikova, S.S. and L’vov, D.K. (2006) Molecular Virological Monitoring of Newcastle Disease Virus Strains (Paramyxoviridae, Avulavirus) in the Populations of Wild Birds in the Volga Estuary (the 2001 Data). Voprosy Virusologii, 51, 32-38.

[7] Diel, D.G., Miller, P.J., Wolf, P.C., Mickley, R.M., Musante, A.R., Emanueli, D.C., Shively, K.J., Pedersen, K. and Afonso, C.L. (2012) Characterization of Newcastle Disease Viruses Isolated from Cormorant and Gull Species in the United States in 2010. Avian Diseases, 56, 128-133. http://dx.doi.org/10.1637/9886-081111-Reg.1

[8] Dovc, A., Zorman-Rojs, O., Vergles Rataj, A., Bole-Hribovsek, V., Krapez, U. and Dobeic, M. (2004) Health Status of Free-Living Pigeons (Columba livia domestica) in the City of Ljubljana. Acta Veterinaria Hungarica, 52, 219-226. http://dx.doi.org/10.1556/AVet.52.2004.2.10

[9] Sivay, M.V., Sayfutdinova, S.G., Sharshov, K.A., Alekseev, A.Y., Yurlov, A.K., Runstadler, J. and Shestopalov, A.M. (2012) Surveillance of Influenza A Virus in Wild Birds in the Asian Portion of Russia in 2008. Avian Diseases, 56, 456-463. http://dx.doi.org/10.1637/9868-080111-Reg.1

[10] Sivay, M.V., Silko, N.Y., Sharshov, K.A., Prokudin, A.V., Li, L., Yang, M., Cao, S. and Shestopalov, A.M. (2011) The Role of Wild Goose (Anser) Populations of Russia and the Tibet Plateau in the Spread of the Avian Influenza Virus. Chinese Birds, 3, 140-146. http://dx.doi.org/10.5122/cbirds.2011.0022

[11] Silim, A. and Venne, D. (1989) Comparison of Egg-Yolk and Serum Antibody Titers to Four Avian Viruses by EnzymeLinked Immunosorbent Assay Using Paired Field Samples. Avian Diseases, 33, 643-648. http://dx.doi.org/10.2307/1591138

[12] Beck, J.R., Swayne, D.E., Davison, S., Casavant, S. and Gutierrez, C. (2003) Validation of Egg Yolk Antibody Testing as a Method to Determine Influenza Status in White Leghorn Hens. Avian Diseases, 47, 1196-1199. http://dx.doi.org/10.1637/0005-2086-47.s3.1196

[13] Burnet, F.M. (1943) Human Infection with the Virus of Newcastle Disease of Fowls. The Medical Journal of Australia, 2, 313-314.

[14] Quinn, R.W., Hanson, R.P., Brown, J.W. and Brandly, C.A. (1952) Newcastle Disease Virus in Man. Results of Studies in Five Cases. Journal of Laboratory and Clinical Medicine, 40, 736-743.

[15] Bawell, M.B., LeGier, M., Murrey, F., Schofield, W. and Broun, G.O. (1949) Occurrence of Antihemagglutinins against Newcastle Virus in Human Respiratory Infections with a Possible Instance of Virus Isolation. Journal of Laboratory and Clinical Medicine, 34, 1581-1582.

[16] Evans, A.S. (1955) Pathogenicity and Immunology of Newcastle Disease Virus (NDV) in Man. American Journal of Public Health, 45, 742-745. http://dx.doi.org/10.2105/AJPH.45.6.742 
Scientific Research Publishing (SCIRP) is one of the largest Open Access journal publishers. It is currently publishing more than 200 open access, online, peer-reviewed journals covering a wide range of academic disciplines. SCIRP serves the worldwide academic communities and contributes to the progress and application of science with its publication.

Other selected journals from SCIRP are listed as below. Submit your manuscript to us via either submit@scirp.org or Online Submission Portal.
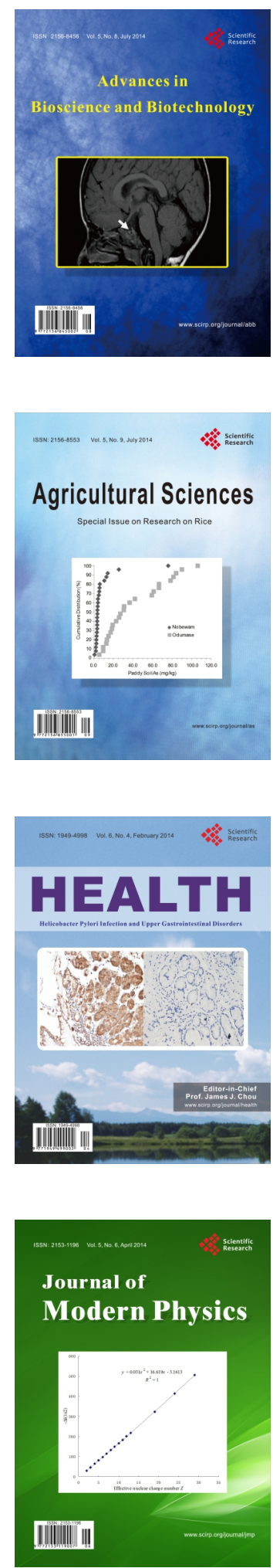
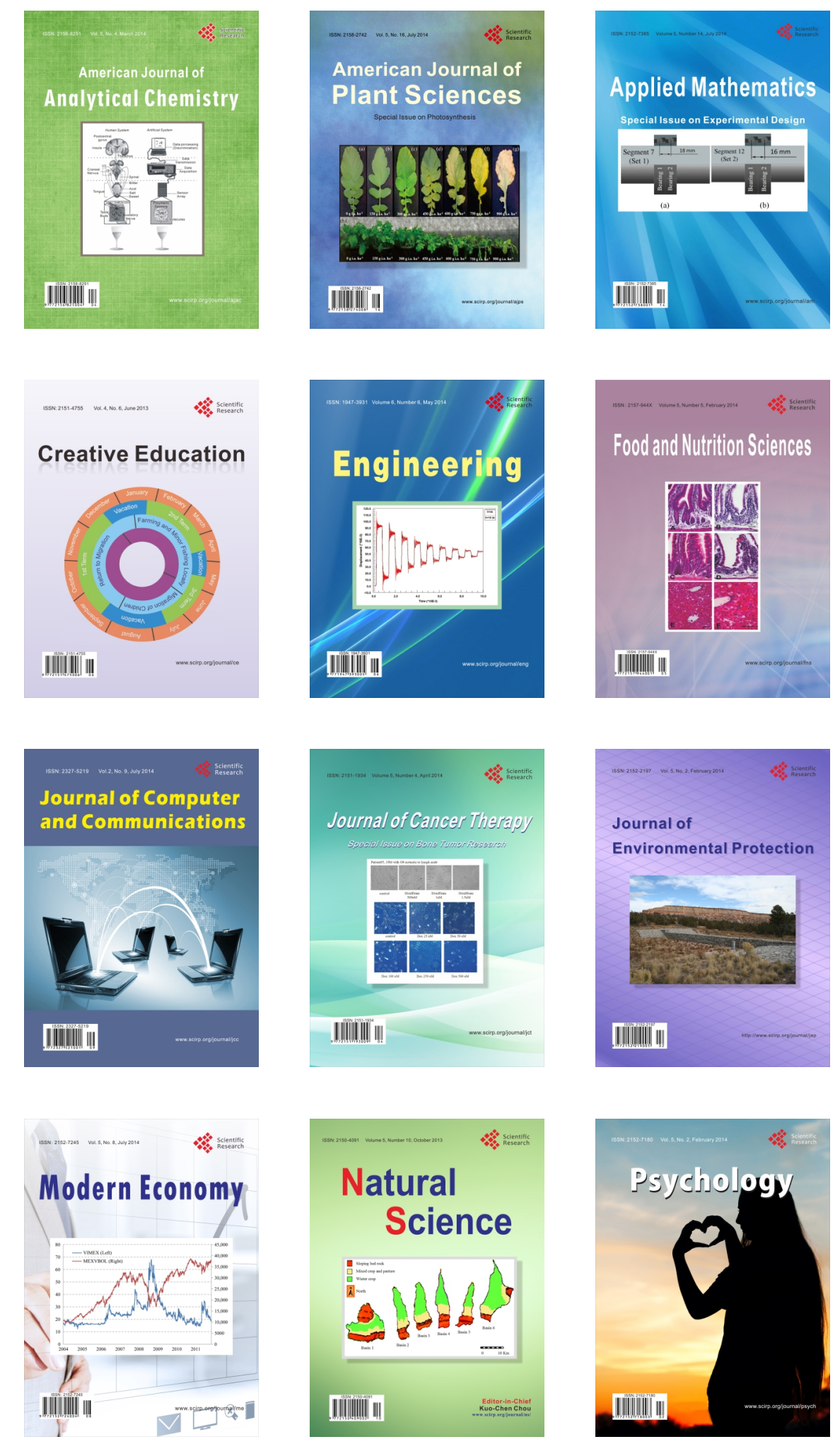